\title{
THE NEOPROTEROZOIC GOIÁS MAGMATIC ARC, CENTRAL BRAZIL: A REVIEW AND NEW Sm-Nd ISOTOPIC DATA
}

\begin{abstract}
MÁRCIO MARTINS PIMENTEL, REINHARDT ADOLFO FUCK AND SIMONE MARIA COSTA LIMA GIOIA
ABSTRACT In this study we review the main characteristics and geochronological/isotopic data of metaigneous rocks of the juvenile Neoproterozoic Goiás Magmatic Arc in central Brazil. Some new Sm-Nd isotopic data are also presented for both the southern (Arenópolis) and northern (Mara Rosa) sections of the arc. In the south, granitoids of the Choupana-Turvânia area yielded a Sm-Nd whole-rock isochron age of $863 \pm 97 \mathrm{Ma}$ and $\mathrm{e}_{\mathrm{Nd}}(\mathrm{T})$ of +4.1 . T model ages vary between 0.94 and $1.13 \mathrm{Ga}$. Metavolcanic rocks in the Pontalina region have a Sm-Nd whole-rock isochron age of $762 \pm 77 \mathrm{Ma}_{\mathrm{Ma}} \mathrm{e}_{\mathrm{Nd}}(\mathrm{T})$ of +2.9 . $\mathrm{T}_{\mathrm{DM}}$ values are between 0.96 and $1.10 \mathrm{Ga}$. In the northern section of the Goiás Arc, mylonitic gneisses of the Serra Azul ridge, an important N30E shear zone, were investigated and have a Sm-Nd isochron age of $3058 \pm 120 \mathrm{Ma}$ and initial $\mathrm{e}_{\mathrm{Nd}}$ value of ca. +2.1. This data suggests that the Serra Azul ridge might represent either a mylonitized fragment of the Archaean terranes exposed just to the south, or the sialic basement of the Araguaia Belt supracrustals, along the eastern margin of the Amazon Craton. The geochronological data available so far indicate a long history of arc formation and amalgamation on the western margin of the São Francisco-Congo continent during the Neoproterozoic. The history of convergence of continental masses is partially coeval with the fragmentation of Rodinia, indicating that the western margin (present geographic reference) of that continent occupied a peripheral setting in the Rodinia supercontinent.
\end{abstract}

Keywords: Goiás Magmatic Arc, Neoproterozoic, Brasiliano

INTRODUCTION The Goiás Magmatic Arc (Pimentel and Fuck 1992) constitutes one of the most important components of the Neoproterozoic Brasília Belt in central Brazil. During the last decade, the discovery of several juvenile metavolcanic and orthogneissic units represented a major step to constrain the geological evolution of this Neoproterozoic orogen (Pimentel et al. 1997, Viana et al. 1995, Rodrigues et al. 1999, Gioia 1997, Pimentel and Junges 1997). However, detailed studies on the field, geochronological and isotopic characteristics of the rock units constituting the Goiás Magmatic Arc are still scarce. Therefore, the stratigraphic and structural relationships between the volcanic and plutonic rock units and even the real geographical/geological limits of the juvenile arc and its relationships with older adjacent terranes are still poorly constrained. In this study we present a review of the geological and geochronological data for the arc rocks and also present some new Sm-Nd isotopic data, which helped to constrain the extension of the juvenile terranes in northern and southern areas of the arc.

THE GOIÁS MAGMATIC ARC

Two main areas of Neoproterozoic juvenile crust have been identified in western and northern Goiás. These are here referred to as the Arenópolis and Mara Rosa arcs respectively (Figure 1). Most of the arc magmatism is represented, at the present level of erosion, by metaplutonic rocks ranging in composition from tonalite to granodiorite. They are exposed between narrow NNW to NNE belts of Neoproterozoic volcanosedimentary sequences.

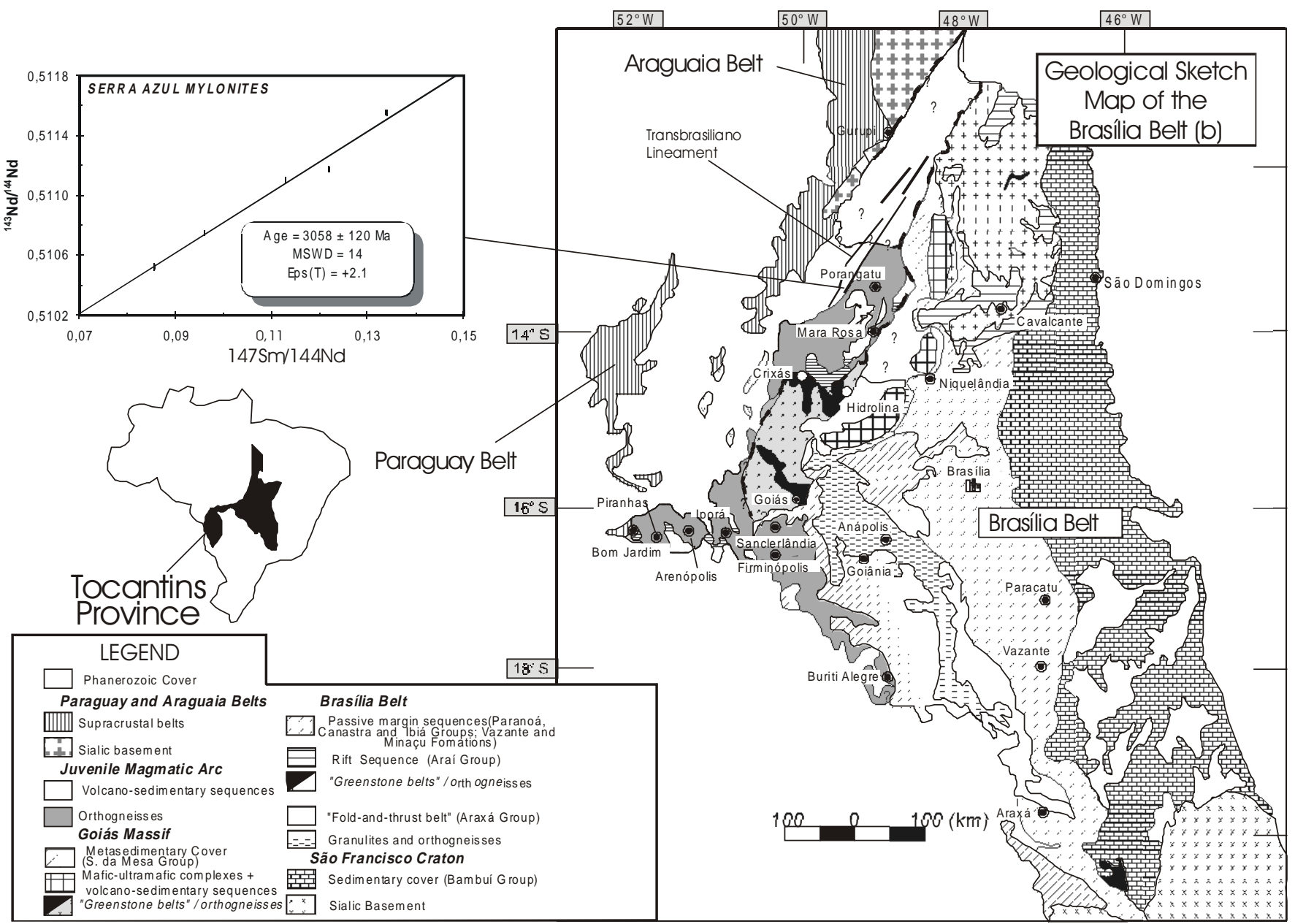

Figure 1 - Geological sketch map of the Brasília Belt, in the eastern part of the Tocantins Province, central Brazil 
The Arenópolis Arc The section of the magmatic arc known as the Arenópolis arc underlies large areas in southwestern and southern Goiás, extending from the vicinities of Bom Jardim de Goiás in the west, to Firminópolis (Fig. 1). The supracrustal and orthogneissic units that make this section of juvenile Neoproterozoic continental crust are juxtaposed to each other along important NNE to NNW strike-slip faults, which are part of the continental-scale Transbrasiliano Lineaments.

Large late- to post-orogenic K-rich granite bodies emplaced into the arc rocks at the end of the Neoproterozoic and beginning of the Paleozoic (Pimentel et al. 1996).

CALCIC- TO CALC-ALKALINE ORTHOGNEISSES These are hornblende- and biotite-bearing metatonalites and metagranodiorites (e.g. the Arenópolis, Sanclerlândia, Matrinxã, and Firminópolis gneisses). They show mineral assemblages indicative of metamorphism under epidote amphibolite facies and commonly display relict igneous textures and structures, such as mafic enclaves, porphyritic textures and magma mixing features. Major and trace element data suggest that the igneous protoliths were metaluminous, calcic- to calc-alkaline, with high $\mathrm{CaO}, \mathrm{MgO}, \mathrm{P}_{2} \mathrm{O}_{5}$ and $\mathrm{Al}_{2} \mathrm{O}_{3}$ (Pimentel 1991). Low Rb/Sr, Zr, Nb, Y, LREE and Ga of the Arenópolis, Sanclerlândia and Firminópolis gneisses are comparable to values found in primitive M-type granitoids of intraoceanic island arcs. Low $\mathrm{K}_{2} \mathrm{O} / \mathrm{Na}_{2} \mathrm{O}$, high $\mathrm{Ni}$, Cr and $\mathrm{Sr}$ contents, and strongly fractionated $\mathrm{REE}$ patterns with high $\mathrm{La} / \mathrm{Yb}$ and $\mathrm{Sr} / \mathrm{Yb}$ ratios are features similar to modern adakites, which form in subduction environments where the subducted slab is young $(<20 \mathrm{Ma})$ and hot and therefore capable of

Table 1 - Summary of geochronological and isotopic data for rock units of the Goiás Magmatic Arc.

\begin{tabular}{|c|c|c|c|c|c|}
\hline Rock Unit & Age (Ma) & $\left({ }^{87} \mathrm{Sr} /{ }^{86} \mathrm{Sr}\right)_{\mathrm{i}}$ & $\mathrm{T}_{\mathrm{DM}}(\mathrm{Ga})$ & $\varepsilon_{\mathrm{Nd}}(\mathrm{T})$ & Refer \\
\hline \multicolumn{6}{|l|}{ Orthogneisses } \\
\hline Arenópolis gneiss & $\begin{array}{c}899 \pm 7^{\mathrm{a}} \\
818 \pm 57^{\mathrm{b}} \\
637^{\mathrm{c}}\end{array}$ & 0.7042 & $1.0-1.2$ & $+1.9 /+3.2$ & 1,2 \\
\hline Matrinxã gneiss & ca. $895^{\text {b }}$ & 0.7026 & 0.9 & +6.0 & 2 \\
\hline Sanclerlândia gneiss & ca. $940^{\text {b }}$ & 0.7025 & $0.9-1.0$ & $+4.0 /+6.0$ & 2 \\
\hline Firminópolis gneiss & $628 \pm 65^{\mathrm{d}}$ & & $1.1-1.4$ & -1.7 & 3 \\
\hline Mara Rosa tonalite gneiss & $\begin{array}{c}856 \pm 13^{\mathrm{a}} \\
600 \pm 136^{\mathrm{b}} \\
517 \pm 16^{\mathrm{h}} \\
533 \pm 16^{\mathrm{h}} \\
\end{array}$ & 0.7032 & $0.9-1.0$ & +4.6 & 8,7 \\
\hline Porangatu granite-gneiss & $589 \pm 61^{\mathrm{b}}$ & 0.705 & & & 12 \\
\hline \multicolumn{6}{|l|}{ Mylonitic granites } \\
\hline Santa Fé granite-gneiss & $467 \pm 10^{\mathrm{b}}$ & 0.705 & & & 4 \\
\hline Serra do Tatu granite & $692 \pm 110^{\mathrm{b}}$ & 0.7062 & & & 5 \\
\hline Porphyritic granite - Jaupaci & $643 \pm 19^{\mathrm{b}}$ & 0.7032 & 0.95 & $+3.2 /+3.5$ & 2 \\
\hline $\begin{array}{l}\text { Mylonitic granite west of the Iporá } \\
\text { sequence }\end{array}$ & $673 \pm 75^{\mathrm{b}}$ & 0.7048 & $1.0-1.1$ & $+0.4 /+1.9$ & 6 \\
\hline \multicolumn{6}{|l|}{ Volcano-Sedimentary Sequences } \\
\hline Metarhyolite-Arenópolis Sequence & $\begin{array}{c}929 \pm 8^{\mathrm{a}} \\
933 \pm 60^{\mathrm{b}} \\
594^{\mathrm{c}}\end{array}$ & 0.7035 & $0.9-1.2$ & $+2.5 /+5.8$ & 1 \\
\hline Anphibolite - Arenópolis Sequence & $859 \pm 43^{\mathrm{e}}$ & & & & 7 \\
\hline Mylonitic meta-rhyolite - Fazenda Nova & $600 \pm 31^{\mathrm{b}}$ & 0.7036 & $0.9-1.1$ & $+0.2 /+2.4$ & 2 \\
\hline Meta-rhyolite - Jaupaci Sequence & $\begin{array}{l}764 \pm 14^{\mathrm{a}} \\
594 \pm 37^{\mathrm{b}}\end{array}$ & 0.7052 & $0.9-1.0$ & $+3.8 /+4.7$ & 1,2 \\
\hline Meta-rhyolite - Iporá Sequence & $\begin{array}{l}636 \pm 6^{\mathrm{a}} \\
597 \pm 5^{\mathrm{a}}\end{array}$ & & $1.0-1.1$ & $+0.6 /+5.0$ & 6 \\
\hline Amphibolite - Mara Rosa & $730 \pm 37^{\mathrm{e}}$ & & & & 7 \\
\hline Felsic metavolcanic - Chapada & $561 \pm 9^{\mathrm{b}}$ & 0.7041 & & & 10 \\
\hline Biotite schist - Chapada & $\begin{array}{l}524 \pm 2^{\mathrm{f}} \\
532 \pm 1^{\mathrm{f}}\end{array}$ & & & & 10 \\
\hline Garnet biotite schist - Mara Rosa & ca. $560^{\mathrm{b}}$ & 0.7045 & $0.9-1.0$ & & 8 \\
\hline Mylonite - Mara Rosa central belt & $603 \pm 135^{\mathrm{b}}$ & 0.7035 & & & 9 \\
\hline $\begin{array}{l}\text { Granada micaschist Mara Rosa western } \\
\text { belt }\end{array}$ & $\begin{array}{l}733 \pm 75^{\mathrm{g}} \\
765 \pm 75^{\mathrm{g}} \\
604 \pm 66^{\mathrm{g}} \\
610 \pm 52^{\mathrm{g}} \\
\end{array}$ & & $0.9-1.0$ & $-3.0 /+2.0$ & 11 \\
\hline Felsite - Posse Mine, Mara Rosa & $\begin{array}{l}862 \pm 8^{\mathrm{a}} \\
632 \pm 4^{\mathrm{c}}\end{array}$ & & $1.0-1.1$ & +3.7 & 8 \\
\hline
\end{tabular}

a - Zircon U-Pb age; b - Whole-rock Rb-Sr isochron; c - Sphene U-Pb age; d - Whole-rock Sm-Nd age; e - K-Ar amphibole date; f $\mathrm{Rb}$-Sr mineral isochron; $\mathrm{g}-\mathrm{Sm}-\mathrm{Nd}$ garnet-whole rock date; $\mathrm{h}$ - K-Ar biotite age. References: 1 - Pimentel et al. 1991; 2 - Pimentel and Fuck 1994; 3 - Pimentel and Gioia 1997; 4 - Barbour et al, 1979; 5 - Pimentel et al. 1985; 6 - Rodrigues 1996; 7 - Hasui and Almeida 1970; 8 - Pimentel et al. 1997; 9 - Viana et al. 1995; 10 - Richardson et al. 1988; 11 - Pimentel et al. 1998; 12 - Tassinari et al. (1981 


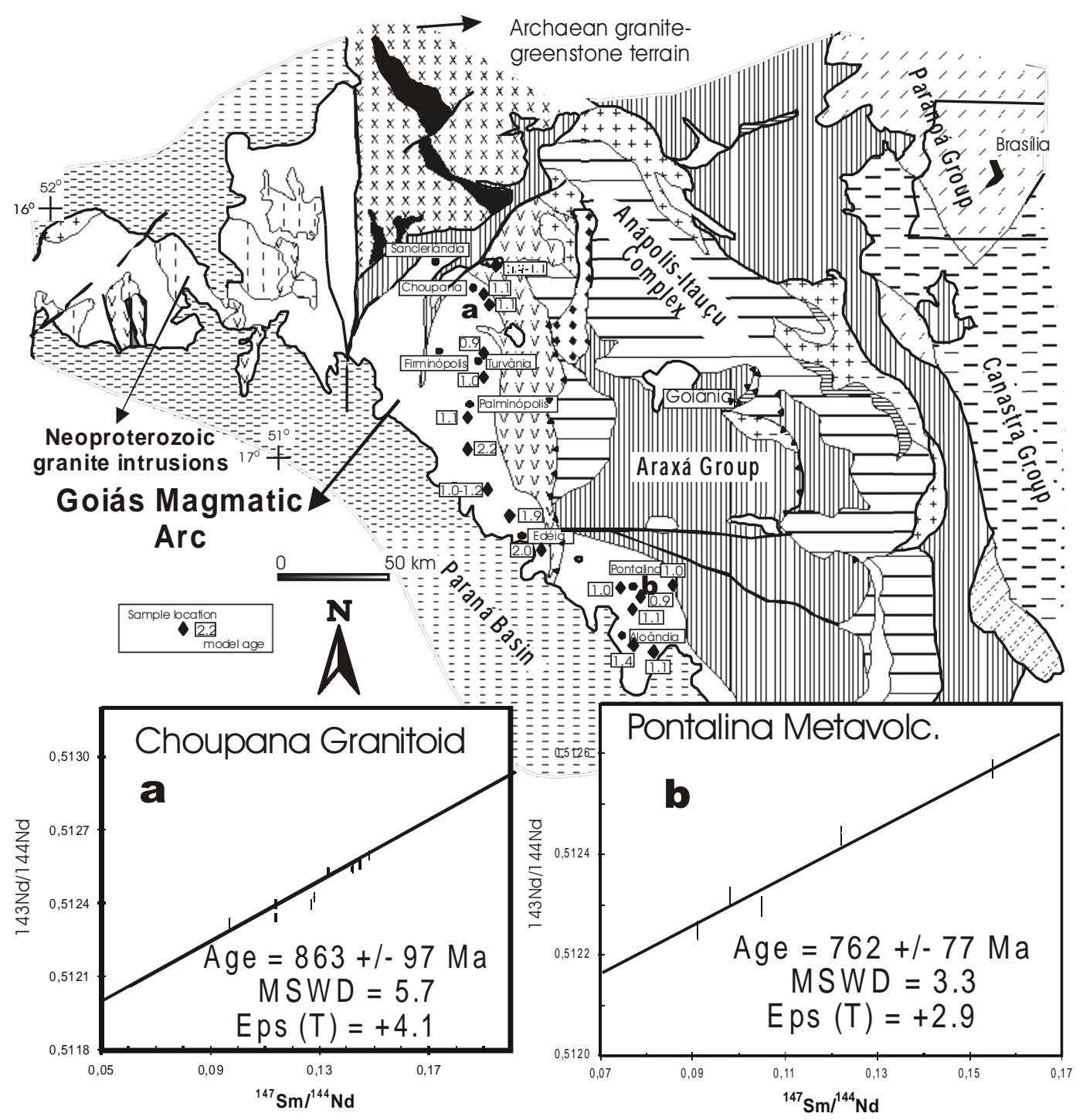

Figure 2 - Geological scketch map of the southern part of the Goiás Magmatic Arc with the new Sm-Nd isotopic data.

undergoing partial melting. $\mathrm{U}-\mathrm{Pb}, \mathrm{Sm}-\mathrm{Nd}$ and $\mathrm{Rb}-\mathrm{Sr}$ isotopic determinations indicate ages between ca. 940 and 630 Ma (see summary in Table 1). Initial ${ }^{87} \mathrm{Sr} /{ }^{86} \mathrm{Sr}$ ratios are low $(<0.705)$ and $\varepsilon_{\mathrm{Nd}}(\mathrm{T})$ values are positive indicating the juvenile character of the original magmas.

Hornblende-bearing granitoids exposed in the vicinities of Choupana and Turvânia (Fig. 2) have been investigated in this study. $\mathrm{T}_{\mathrm{DM}}$ model ages are between ca. 0.94 and $1.13 \mathrm{Ga}$ (Table 2). A whole rock Sm-Nd isochron indicates the age of $863 \pm 97 \mathrm{Ma}$ and $\varepsilon_{\mathrm{Nd}}(\mathrm{T})$ of +4.1 , indicating the primitive nature of the protolith (Figure 2 ).

To the south of Turvânia, however, orthogneisses have Paleoproterozoic model ages (1.89 to $2.27 \mathrm{Ga}$ ) (Figure 2, Table 2), indicating the involvement of older sialic crust in between the Neoproterozoic juvenile rocks. Examples of involvement of small blocks of older rocks in between the juvenile rock units have been described in previous studies in the Arenópolis arc (Pimentel 1992, Rodrigues et al. 1999).

MYLONITIC GRANITES Mylonitic granitic and granodioritic rocks occurring as narrow bodies elongated parallel to the NNW-NNE strike-slip faults are common in southwestern Goiás. They are metaluminous or slightly peraluminous and show geochemical characteristics similar to the high-K calc-alkaline series (Rodrigues 1996), being distinctively more evolved geochemically than the orthogneisses discussed above. $\mathrm{Rb}-\mathrm{Sr}$ isotopic data for these rocks indicate isochron ages varying from ca. 470 to $690 \mathrm{Ma}$ and initial ${ }^{87} \mathrm{Sr} /$ ${ }^{86} \mathrm{Sr}$ ratios between 0.7032 and 0.7062 . Sm-Nd $\mathrm{T}_{\mathrm{DM}}$ model ages are between 0.95 and $1.1 \mathrm{Ga}$ and initial $\varepsilon_{\mathrm{Nd}}$ values are positive (+0.4 to +3.5 , Table 1).

VOLCANO-SEDIMENTARY SEQUENCES Several NNW to NNE strips of volcano-sedimentary rocks are known in western/ southwestern Goiás. From west to east these are the Bom Jardim de Goiás, Arenópolis, Iporá/Amorinópolis and Jaupaci sequences. The Bom Jardim de Goiás Sequence consists of greenschist facies metabasalts, metandesites and metarhyolites (Seer 1985). The upper unit of the supracrustal sequence is made mainly of detrital sediments (metaconglomerates, metarkoses, metasiltstones and phyllites)

The Arenópolis Sequence (Pimentel and Fuck 1986) is formed by two main units, separated from each other by a very narrow strip of strongly deformed banded gneisses displaying Archaean $\mathrm{T}_{\mathrm{DM}}$ model ages (the Ribeirão gneiss, Pimentel 1992). The western Corrego do Santo Antônio Unit is made mainly of metapelites with garnet, staurolite, kyanite and sillimanite, marbles, calc-silicate rocks, metacherts, gondites and mafic-ultramafic bodies and is interpreted as an accretionary wedge (Pimentel and Fuck 1986). The Córrego da Onça Unit, east of the Ribeirão gneiss, is dominated by calc-alkaline metavolcanics including metabasalts, metandesites, metadacites and metarhyolites, with lesser amounts of low-K metatholeiites, metagraywackes, fine-grained quartzites and metacherts. Geochemical data for these rocks (low $\mathrm{K}, \mathrm{K} / \mathrm{Na}, \mathrm{Rb}$ and $\mathrm{REE}$ ) suggest a very primitive nature for the original magma, which is confirmed by $\mathrm{Sm}-\mathrm{Nd}$ isotopic data which show $\varepsilon_{\mathrm{Nd}}(\mathrm{T})$ between +2.5 and +2.8 (Pimentel and Fuck 1992). The volcano-sedimentary sequences in the Iporá area 
Table 2 - New Sm-Nd isotopic data for metaigneous rock units of the Goiás Magmatic Arc.

\begin{tabular}{|c|c|c|c|c|c|}
\hline Sample & $\begin{array}{c}\mathrm{Sm} \\
(\mathrm{ppm})\end{array}$ & $\begin{array}{c}\mathrm{Nd} \\
(\mathrm{ppm})\end{array}$ & $\begin{array}{l}147 \mathrm{Sm} / \\
144 \mathrm{Nd}\end{array}$ & $\begin{array}{c}143 \mathrm{Nd} / 144 \mathrm{Nd} \\
( \pm 1 \sigma)\end{array}$ & $\mathrm{T}_{\mathrm{DM}}(\mathrm{Ga})$ \\
\hline CHOUP-1 & 2.476 & 11.71 & 0.128 & $0.512426(10)$ & 1.09 \\
\hline TUR-1E & 1.749 & 10.89 & 0.097 & $0.512320(08)$ & 0.94 \\
\hline TUR-1A & 1.92 & 10.22 & 0.114 & $0.512395(09)$ & 0.99 \\
\hline CHOUP-4 & 1.787 & 7.452 & 0.145 & $0.512559(20)$ & 1.07 \\
\hline CHOUP-5 & 1.651 & 7.023 & 0.142 & $0.512540(21)$ & 1.06 \\
\hline TUR-2A & 3.66 & 19.47 & 0.114 & $0.512342(15)$ & 1.07 \\
\hline AMB-1 & 3.02 & 14.34 & 0.127 & $0.512396(13)$ & 1.13 \\
\hline AMB-2 & 3.318 & 15.41 & 0.133 & $0.512526(12)$ & 0.97 \\
\hline FSP-2635 & 1.882 & 7.663 & 0.148 & $0.512596(24)$ & 1.03 \\
\hline PONT-1 & 7.343 & 45.09 & 0.098 & $0.512317(23)$ & 0.96 \\
\hline PONT-3 & 3.807 & 21.96 & 0.105 & $0.512296(45)$ & 1.06 \\
\hline PONT-4A & 3.630 & 24.08 & 0.091 & $0.512249(21)$ & 0.99 \\
\hline PONT-2 & 8.403 & 41.54 & 0.122 & $0.512438(07)$ & 0.91 \\
\hline PONT-4C & 5.010 & 19.50 & 0.155 & $0.512570(05)$ & 1.10 \\
\hline $\begin{array}{c}\text { PONT-4B } \\
\text { (amphibolite) }\end{array}$ & 7.014 & 39.92 & 0.106 & $0.512164(12)$ & 1.23 \\
\hline EDE-2A & 10.49 & 51.43 & 0.123 & $0.511818(08)$ & 2.04 \\
\hline EDE-1C & 7.786 & 35.93 & 0.130 & $0.511926(08)$ & 2.00 \\
\hline INDI-1A & 18.85 & 99.56 & 0.114 & $0.511798(09)$ & 1.89 \\
\hline PALM-2A & 3.620 & 16.47 & 0.133 & $0.512504(14)$ & 0.98 \\
\hline PALM-2B & 6.903 & 47.32 & 0.088 & $0.512010(13)$ & 1.25 \\
\hline PALM-1B & 5.700 & 31.32 & 0.110 & $0.511548(09)$ & 2.19 \\
\hline PALM-1A & 4.476 & 22.75 & 0.119 & $0.511626(23)$ & 2.27 \\
\hline ALO-1 & 5.891 & 27.70 & 0.128 & $0.512219(20)$ & 1.45 \\
\hline ALO-2 & 3.771 & 18.68 & 0.122 & $0.512365(12)$ & 1.12 \\
\hline PORANG-2 & 2.560 & 12.64 & 0.122 & $0.511176(12)$ & 3.12 \\
\hline PORANG-3 & 1.158 & 5.231 & 0.134 & $0.511549(23)$ & 2.87 \\
\hline PORANG-8 & 3.194 & 20.04 & 0.096 & $0.510752(18)$ & 2.97 \\
\hline PORANG-9 & 2.560 & 18.10 & 0.0855 & $0.510520(09)$ & 3.01 \\
\hline PORANG-10 & 2.850 & 15.21 & 0.113 & $0.511100(10)$ & 2.95 \\
\hline
\end{tabular}

(Iporá, Jaupaci and Amorinópolis sequences) are poor in intermediate volcanic rocks, comprising bimodal suites.

In the Pontalina area (Fig. 2), new isotopic data presented in this study reveal that metavolcanic rocks exposed in that area also have juvenile Sm-Nd isotopic signature (Table 2). $\mathrm{T}_{\mathrm{pM}}$ model ages for felsic rocks are between 0.96 and $1.10 \mathrm{Ga}$ and a whole-rock isochron (Figure 2 ) indicate the age of $762 \pm 77 \mathrm{Ma}$ and $\varepsilon_{\mathrm{Nd}}(\mathrm{T})$ of +2.9 . This new data shows that juvenile terranes extend well far to the east, close to the westernmost outcrops of the sedimentary sequences of the Brasília Belt (Araxá Group), demonstrating the very widespread distribution of the arc units in southwestern Goiás.

\section{LATE- TO POST-OROGENIC GRANITIC MAGMATISM AND} ASSOCIATED MAFIC AND ULTRAMAFIC BODIES The last tectono-metamorphic event in the Brasília Belt happened between 0.63-0.59 Ga (U-Pb and Sm-Nd garnet ages). This was responsible for the development of: (i) W-NW dipping foliation showing kinematic indicators revealing tectonic transport to the east (e.g. in the Mara Rosa arc area), and (ii) wide and long subvertical, dominantly NE-trending mylonite zones, such as the Transbrasiliano Lineament (Fig. 1).

During the waning stages or immediately after this last deformation, a number of small mafic-ultramafic layered complexes, gabbro-dioritic intrusions, and large granite plutons were emplaced into the western part of the Brasília Belt. The gabbro-dioritic intrusions and maficultramafic layered complexes (e.g. Lajeado intrusion and Americano do Brasil Complex, in western Goiás) are either only slightly deformed or completely free of any pervasive deformational fabric. The Ameri- cano do Brasil Complex, for example, is a small layered intrusion (peridotite to gabbro) and the original tholeiitic parental magma displays arc characteristics (Nilson 1981). Gabbro and diorite also occur as small bodies inside the larger granite intrusions. Some of these gabbro-dioritic intrusions have been dated by the $\mathrm{Rb}-\mathrm{Sr}$ isochron, giving poorly constrained ages of ca. 610-630 Ma with initial ${ }^{87} \mathrm{Sr} /{ }^{86} \mathrm{Sr}$ ratios of ca. 0.703-0.704, suggesting little contamination with older sialic crust material (for a review see Pimentel et al. 1996). The Americano do Brasil complex was recently dated by the Sm-Nd method at $612 \pm 66 \mathrm{Ma}$, with an initial $\varepsilon_{\mathrm{Nd}}$ value of +3.1 also indicating little or no contamination with ancient crust (Nilson et al. 1997).

The granite intrusions form large bodies of K-rich calc-alkaline granites (e.g. Serra Negra, Serra do Iran, Caiapó, Iporá, Sanclerlândia and Serra do Impertinente granites)(Pimentel et al. 1996). Most are completely undeformed and made exclusively of equigranular biotite granites, although some have hornblende-bearing and porphyritic facies (e.g. the Caiapó granite, Pimentel et al. 1996). In a broad regional scale, this igneous event is typically bimodal and has been associated with post-orogenic uplift and extension.

The Mara Rosa Arc In northern Goiás and southern Tocantins, the Goiás Magmatic Arc is made largely of tonalitic/dioritic orthogneisses, which underlie large areas in between narrow N20-30E volcano-sedimentary sequences. The rock units comprising the Goiás Magmatic Arc in this region are better known in the area between Porangatu, in the north, and Chapada, in the south (Fig. 1). The extension of these juvenile terranes towards the north is still unknown due to the lack of geochronological data.

ORTHOGNEISSES In the Mara Rosa - Chapada area, these are medium- to coarse-grained dioritic to tonalitic metaplutonic rocks. They are geochemically very primitive with $\mathrm{SiO}_{2}$ contents smaller than $60 \%$, display calcic to calc-alkaline character with low $\mathrm{Rb}, \mathrm{Nb}, \mathrm{Y}, \mathrm{Zr}$ and REE, being similar to M-type granitoids of immature island arcs (Viana et al. 1995).

Geochronologic and isotopic data for these rocks are in Table 1. U$\mathrm{Pb}$ zircon data indicate crystallization of the protolith at $856 \pm 13 \mathrm{Ma}$. $\mathrm{Nd}$ isotopic data, similarly to the orthogneisses from the Arenópolis area, indicate the very primitive nature of the original magma, with $\mathrm{T}_{\mathrm{DM}}$ values of ca. $0.9-1.0 \mathrm{Ga}$ and $\varepsilon_{\mathrm{Nd}}(\mathrm{T})$ of +4.6.

Mylonitic orthogneisses exposed along the Serra Azul shear zone, west of Porangatu, were investigated in this study and yielded Archaean model ages ranging from 2.9 to $3.1 \mathrm{Ga}$ (Fig. 1; Table 2). A $\mathrm{Sm}-\mathrm{Nd}$ whole-rock isochron for these rocks indicates the age of 3058 $\pm 120 \mathrm{Ma}$ and initial $\varepsilon_{\mathrm{Nd}}$ value of ca. +2.1 (Figure 1). This data suggests that the Serra Azul ridge might represent either a mylonitized fragment of the Archaean terranes exposed just to the south, in the Crixás area, or the sialic basement of the Araguaia Belt supracrustals, along the eastern margin of the Amazon Craton.

THE SUPRACRUSTAL BELTS In the region between Chapada and Porangatu, regional mapping projects have identified a number of individual volcano-sedimentary sequences (Machado et al. 1981, Ribeiro Filho 1981, Lacerda 1986, Arantes et al. 1991, Kuyumjian 1989). In the Mara Rosa area, the supracrustal belts are made of metabasalt, intermediate and felsic metatuffs, fine-grained graywackes, garnet micaschist, chert, iron formations, quartzites and ultramafic rocks, metamorphosed in greenschist to amphibolite facies conditions. Within the supracrustal belts, small-elongated bodies of mylonitic granites have also been recognized (Palermo 1996), some of which were previously misinterpreted as metavolcanic rocks. Amphibolites of the Mara Rosa sequence are either tholeiitic, rich in $\mathrm{Mg}, \mathrm{Ni}$ and $\mathrm{Cr}$ and similar to boninites, or calc-alkaline. According to Palermo (1996), the former could represent fragments of the oceanic crust and the latter are related to the arc magmatism. In the Chapada area, the garnet and epidote amphibolites are chemically similar to modern arc tholeiites and were interpreted as being originated in a back arc setting (Kuyumjian 1994).

Detrital metasediments represented by feldspathic garnet micaschist and fine-grained biotite gneisses have $\mathrm{T}_{\mathrm{DM}}$ values in the range 0.9-1.2 $\mathrm{Ga}$, with only one analysis yielding a significantly older model age of $1.6 \mathrm{Ga}$. This indicates that they are the products of erosion of the arc rocks, with little contribution from older sources. The deposition of the original sediments must have taken place far from any old continental source area and probably happened in an intraoceanic setting. Sm-Nd garnet-whole rock isochrons for these metasediments indicate ages of ca. 733, 765, 604 and $610 \mathrm{Ma}$. These were interpreted as resulting 
from two metamorphic episodes: an early one at ca. $760 \mathrm{Ma}$ and a later metamorphism with typical Brasiliano ages (Junges 1998, Pimentel and Junges 1997).

CONCLUSIONS The new Sm-Nd isotopic data indicate that the juvenile terranes of the Neoproterozoic magmatic arc in central Brazil underlie very large areas especially in the southwestern part of the Brasília Belt. In the southern part of the arc, juvenile rock units are found along a ca. $250 \mathrm{~km}$ long traverse in the E-W direction. Although most of the Neoproterozoic arc rocks show juvenile character, in some localities the igneous activity seem to have involved older (ArchaeanPaleoproterozoic) small continental blocks.

The evolution of these arc terranes started in intraoceanic island arc settings at ca. $900 \mathrm{Ma}$. Igneous activity happened during most of the Neoproterozoic, and there is a trend of increasing maturity of the magmatism towards the end of the Proterozoic.

Metamorphic ages suggest that at least some of these arc terranes were accreted to the western margin of the São Francisco continent at ca. $0.78-0.75 \mathrm{Ga}$. These juvenile terranes were later involved in the continental collision between the São Francisco and Amazon continents at ca. $620 \mathrm{Ma}$ (the Brasiliano orogeny).

This history of convergence of continental masses is in part coeval with the fragmentation of Rodinia, indicating that the western margin (present geographic reference) of the São Francisco-Congo continent occupied a peripheral setting in Rodinia, along which subduction occurred at the same time as the supercontinent broke up.

Acknowledgements The authors are grateful to Conselho Nacional de Desenvolvimento Científico e Tecnológico - CNPq for Research Grant to Márcio Pimentel (Proc. 000400166/97) and for funding part of the field and lab work (Proc. no 52.0682/94). FAP-DF (Proc. No 193.000.068/96) also provided funds for field and laboratory work. Two anonymous referees of RBG are also acknowledged for their critical review of the manuscript and helpful suggestions.

\section{References}

Arantes D., Osborne G.A., Buck P.S., Porto C.G. 1991. The Mara Rosa volcanosedimentary sequence and associated gold mineralization. In: Brazil Gold '91(Edited by Ladeira,E.A.) p. 221-229, Balkema, Rotterdam

Barbour A.P., Girardi V.A.V., Kawashita K., Souza A.M.S. 1979. Geologia do complexo máfico-ultramáfico alcalino de Santa Fé, Goiás. Boletim IG-USP, 10:11-18.

Gioia S.M.C. 1997. Preparação da Metodologia Sm-Nd para Datação de Amostras Geológicas e sua Aplicação em Rochas das áreas de Firminópolis, Fazenda Nova e Americano do Brasil. MSc Dissertation, UnB, Brasília, 100p.

Hasui Y. and Almeida F.F.M.de. 1970. Geocronologia do centro-oeste brasileiro. Bol. Soc. Bras. Geologia, 19:5-26.

Junges S.L. 1998. Características geoquímicas e isotópicas dos metassedimentos da seqüência vulcano-sedimentar de Mara Rosa - GO. MSc Dissertation, UnB, Brasília, $120 \mathrm{p}$.

Kuyumjian R.M. 1989. Geoquímica e significado do posicionamento geotectônico de rochas plutônicas da região de Chapada, Goiás, Brasil. Anais, XXXIII Congresso Brasileiro de Geologia, Rio de Janeiro, SBG-CPRM p. 195-201.

Kuyumjian R.M. 1994. Geologia da seqüência Mara Rosa na região de Chapada, Goiás. Anais, IV Simpósio de Geologia do Centro-Oeste, Brasília, SBG p.142-144.

Lacerda H. 1986. As mineralizações auríferas da região de Mara Rosa (GO). Revista Brasileira de Geociências, 16(3):274-284

Machado E.C., Souza C.J.M., Silva M.A., Berbert C.O.1981. Projeto Porangatu - relatório final. Etapa II, DNPM/CPRM, 1, 246p.

Nilson A.A.1981. The nature of the Americano do Brasil mafic-ultramafic complex and associated sulfide mineralization, Goiás, Brasil. PhD Thesis, University of Western Ontario, 460p.

Nilson A.A, Gioia S., Pimentel M.M. 1997. Idade Sm-Nd do Complexo Máfico-Ultramáfico de Americano do Brasil, Goiás e características isotópicas das rochas encaixantes. Anais, VI Cong. Bras. Geoquím., Salvador, SBGq, pp.643-645.

Palermo N. 1996. Le gisement aurifère précambrien de Posse (Goiás, Brésil) dans sons cadre géologique. These de doctorat. ENSMP, Paris, $175 \mathrm{p}$.

Pimentel M.M. 1991. Late Proterozoic Crustal Evolution of the Tocantins Province in central Brazil: an Isotopic and Geochemical Study. DPhil Thesis, University of Oxford, $250 \mathrm{p}$.

Pimentel M.M.1992.Reajuste do sistema isotópico Sm-Nd durante o Neoproterozóico em gnaisses do oeste de Goiás. Revista Brasileira de Geociências, 22(4):1-7.

Pimentel M.M. and Fuck R.A. 1986. Geologia da seqüência vulcano-sedimentar de Arenópolis (GO). Revista Brasileira de Geociências,16:217-223.

Pimentel M.M. and Fuck R.A. 1992. Neoproterozoic crustal accretion in central Brazil. Geology, 20(4),375-379.

Pimentel M.M. and Fuck R.A. 1994. Geocronologia Rb-Sr da porção sudoeste do Maciço Mediano de Goiás. Rev. Bras. Geoc., 24(2):104-111.

Pimentel M.M., Fuck R.A., Alvarenga C.J.S.de. 1996. Post-Brasiliano (Pan-African) high$\mathrm{K}$ granitic magmatism in central Brazil: late Precambrian/early Paleozoic extension. Precambrian Research, 80:217-238.
Pimentel M.M., Fuck R.A., Cordani U.G, Kawashita K. 1985. Geocronologia de rochas graníticas e gnáissicas da região de Arenópolis-Piranhas, Goiás. Rev. Bras. Geoc.,15:3-8.

Pimentel M.M., Fuck R.A, Junges S. 1998. New Sm-Nd Isotopic Constraints for the Age of Metamorhic events in the Neoproterozoic Brasília Belt, Central Brazil. Abstracts, 14. International Conference on Precambrian and Craton Tectonics - International Conference on Basement Tectonics, UFOP-International Basement Tectonics Association, Ouro Preto, p.50-52

Pimentel M.M. and Gioia S.M.C.L. 1997 Nd isotopic characteristics of the Firminopolis gneisses and the eastern limits of the Goiás Magmatic Arc. Extended Abstracts, 1. Simpósio Sul-Americano de Geologia Isotópica, Campos do Jordão, pp.234-236

Pimentel M.M., Heaman L., Fuck R.A. 1991. U-Pb zircon and sphene geochronology of late Proterozoic volcanic arc rock units from southwestern Goiás, central Brazil. Journal of South American Earth Sciences., 4,329-339.

Pimentel M.M. and Junges S.L. 1997. Nd Isotopic characteristicss of metasediments of the Neoproterozoic Mara Rosa Arc, Goiás, Central Brazil. Extended Abstracts, I South American Symposium On Isotope Geology SSAGI, Campos do Jordão, p. 237-239.

Pimentel M.M., Whitehouse M.J., Viana M.G., Fuck R.A., Machado N. 1997. The Mara Rosa arc in the Tocantins Province: further evidence for Neoproterozoic crustal accretion in central Brazil. Precambrian Research, 81,299-310.

Ribeiro Filho W.1981. Reavaliação da geologia de Pilar-Mara Rosa. Atas, I Simpósio de Geologia do Centro-Oeste, Goiânia,p.281-296.

Richardson S.V., Jones J.P., Kesler S.E. 1988. Strontium isotopic geochemistry of Pan African/Brasiliano rocks, Chapada copper deposit, Goiás, Brazil. Geol. Rundschau,
77:763-770.

Rodrigues J.B. 1996. Geocronologia e geoquímica da seqüência vulcano-sedimentar de Iporá e rochas graníticas associadas. MSc Dissertation. UnB, Brasília, $101 \mathrm{p}$.

Rodrigues J.B., Gioia S.M.L.C., Pimentel M.M. 1999. Geocronologia e geoquímica de rochas ortognáissicas da região entre Iporá e Firminópolis: implicações para a evolução do Arco Magmático de Goiás. Revista Brasileira de Geociências, 29(3), in press

Seer H.J. 1985. Geologia, deformação e mineralização de cobre no complexo vulcanosedimentar de Bom Jardim de Goiás. MSc Dissertation, UnB, Brasília, 190 p.

Tassinari C.C.G., Siga Jr. O., Teixeira W. 1981. Panorama geocronológico do centro-oeste brasileiro: soluções, problemática e sugestões. Atas, 1. Simp. Geol. Centro-Oeste, Goiânia, SBG, p. 93-116.

Viana M.G., Pimentel M.M. Whitehouse M.J., Fuck R.A., Machado N. 1995. O Arco Magmático de Mara Rosa, Goiás: Dados geoquímicos e geocronológicos e suas implicações regionais . Revista Brasileira de Geociências ,25: 111-123

Contribution IGC-067

Received February 15, 2000 Accepted for publication April 21, 2000 